P. D. Oldham ${ }^{15}$ in South Wales that the resemblance between first-degree relatives was substantially less for blood pressure than for height.

Thus environmental influences on blood pressure appear to be potentially greater than genetic influences, and evidence of their existence has been obtained in a number of surveys. ${ }^{16} 17$ However, Acheson and Fowler draw attention to other studies $^{1819}$ in which an association was sought but not found between the blood pressures of spouses who had lived together for many years and thus had presumably shared much of their environment. On this rather tenuous basis they are inclined to play down the influence of environment on blood pressure and point out that factors other than environment may reduce the apparent correlations of blood pressure between first-degree relatives. For instance, errors in measurement are likely to be greater for blood pressure than stature. Another difficulty is the use of age and sexadjusted scores in a population whose survival is selective. People with high blood pressure do not survive as long as those with lower pressures, whereas a similar problem does not arise for height. Acheson and Fowler therefore conclude that stature makes a misleading comparison with blood pressure, and they incline to the view that inheritance is the most important single factor in determining the appearance of hypertension.

However, their analysis does not necessarily overthrow Pickering's conclusions. For example, Japanese ${ }^{20}$ and Chinese $^{21}$ have lower blood pressures as young adults than do most other races, yet they are remarkably liable to hypertension in middle age. It is difficult to escape the conclusion that much of that predisposition may be acquired from the environment rather than from genes. Perhaps the most telling investigation ever made on the influence of environment is that by R. Cruz-Coke and his colleagues from the University of Chile. ${ }^{22}$ These authors studied the highly inbred inhabitants of Easter Island both in their own environment and after migration to the mainland. There are apparently no inhabitants of Easter Island who would by any standard be classified as hypertensive, yet after migration to the mainland a genetically almost identical population shows a strong predisposition to hypertension.

Is it possible yet to give a final verdict on the PickeringPlatt controversy? In so far as the theory that inheritance is mainly by a single gene in a dominant manner depends on

Weitz, W., Z. klin. Med., 1923, 96, 151.

Ayman, D., Arch. intern. Med., 1934, 53, 792

Fishberg, A. M., Hypertension and Nephritis, 4th ed., 1939. Philadelphia.

- Bechgaard, P., Acta med. scand, 1964, Suppl. 172.

Søbye, P., Op. dom. Biol. hered. hum. Kbh., $1948,16$.

Von Versohuer, O., and Zipperlen, V., Z. klin. Med., 1929, 112, 69.

'Stocks, P., Ann. Eugen. (Lond.), 1930, 4, 49.

- Kahler, O. H., and Weber, R., Z. klin. Med., 1940, 137, 507.

- Hamilton, M., Pickering, G. W., Roberts, J. A. F., and Sowry, G. S. C., Clin. Sci., 1954, 13, 11, 37, and 273 .

10 Platt, R., Lancet, 1959, 2, 55.

1 Platt, R., Lancet, 1963, 1, 899.

12 Morrison, S. L., and Morris, J. N., Lancet, 1959, 2, 864.

3 Armitage, P., Fox. W., Rose, G. A., and Tinker, C. M., Clin. Sci., 1966, 30, 331 .

14 Acheson, R. M., and Fowler, G. B., f. chron. Dis., 1967, 20, 731.

1s Miall, W. E., and Oldham, P. D., Brit. med. F., 1963, 1, 75.

16 Lowe, C. R., and McKeown, N.'T., Lancet, 1962, 1, 1086.

17 Winkelstein, W., Kantor, S., Ibrahim, M., and Sackett, D. L., F. Amer. med. Ass., 1966, 195, 848 .

18 Gearing, F. R., Clark, E. G., Perera, G. A., and Schweitzer, M. D., Amer. F. publ. Hlth, 1962, 52, 2058. 1. Johnson, B. C., Epstein, F. H., and Kjelsberg, M. O., f. chron. Dis.,

20 Schroeder, H. A., f. chron. Dis., 1958, 8, 287 and 312.

21 Lin, T-Y., Hung, T-P., Chen, C-M., Hsu, T-C., and Chen, K-P., Clin. Sci., 1959, 18, 301.

22 Cruz-Coke, R., Etcheverry, R., and Nagel, R., Lancet, 1964, 1, 697. ss Goldblatt, H., Lynch, J. Hanzal, R. F., and Summerville, W. W.
f. exp. Med., 1934, 59, 347 . breaks in the distribution curve of first-degree relatives of hypertensives, Platt's view is hardly acceptable. Yet it is well to remember that despite massive onslaught the concept of essential hypertension has lost very little ground in the last 20 years. A small amount of renovascular hypertension is recognized, and Dr. P. W. Robertson reports several cases at page 793 of the B.M.f. this week. In addition a few cases of hypertension are associated with phaeochromocytoma and Conn's syndrome. But the great mass remains. Though the single-gene hypothesis cannot really account for the epidemiological observations, many people still believe that it is right to continue the search for a single main cause of essential hypertension. Pickering thinks that such a search is as futile as a search for the cause of above-average stature. Perhaps it is if the search is confined to the possible effects of a single gene. But the search for a single main cause may yet be worth while. Suppose that essential hypertension resulted from the operation of a pathological process which is common to virtually the whole adult population, but yet is different in extent in each member. For example, some common degenerative arterial process might occur in the kidney to a different extent in each individual, and the blood pressure might depend on the extent of this process-a concept that provided the stimulus for Goldblatt's original experiment of constricting the main renal arteries. ${ }^{23}$ Other hypotheses likewise come to mind. Consequently, though we may agree to abandon the single-gene hypothesis to explain essential hypertension, the search for a single and possibly remediable cause may continue to be worth while. At present the epidemiological evidence suggests that if a single cause predisposes to hypertension it must depend on a polygenic inheritance which needs a suitable environment before it can make its effects felt.

\section{Surgical Treatment of Duodenal Ulceration}

In considering the treatment of duodenal ulcer an important question to be answered is this: How does vagotomy combined with drainage compare with the old-established operation of partial gastrectomy with gastrojejunal anastomosis ? ${ }^{1}$

A. G. Cox ${ }^{2}$ compared 55 patients after partial gastrectomy with 51 after vagotomy combined with gastrojejunostomy. The results were marginally better in the latter group in terms of alimentary symptoms, but episodic diarrhoea was less frequent in the former. Thirteen of the patients with vagotomy and nine of those with gastrectomy had diarrhoea, but among those affected the frequency and severity of the attacks was about the same after either operation. A carefully controlled study is needed to obtain valid conclusions. All too often comparisons are made between groups of patients treated by different surgeons in different centres and without a standard system of assessing the results.

In this issue of the B.M.F. an important prospective trial of three types of operation for duodenal ulceration carried out as a combined effort by the surgeons at Leeds and York is reported (pp. 781 and 787). The three operations studied were vagotomy and gastroenterostomy, vagotomy and antrectomy with duodenal closure and gastrojejunal anastomosis, and an ordinary subtotal gastrectomy of the Polya type. 
The organization of the trial was described in detail by Professor J. C. Goligher and his colleagues in 1964. ${ }^{3}$ The trial was restricted to patients undergoing elective surgical treatment for duodenal ulcer. An "escape clause" was introduced, so that if in a particular case the surgeon decided preoperatively that a particular operation was indicated such a patient could be taken out of the trial. Thus the surgeon might consider that a patient who had had pulmonary tuberculosis should not be subjected to gastrectomy. At operation, once again, the surgeon could decide to take the patient out of the trial if it seemed that a particular operation was necessary. The usual case was that of a deeply penetrating posterior ulcer, when gastrectomy might be hazardous and vagotomy with gastrojejunostomy more appropriate. But once the surgeon had decided at operation that the patient was suitable for entry into the trial then a sealed envelope of instruction was opened to discover which of the three operations was to be performed. The envelopes had been prearranged to give a random distribution of the different operations under trial. Subsequent follow-up was carried out by a small panel who generally did not know which operation has been performed until after they had recorded their findings and verdict. This assessment of results has been conducted yearly.

The trial now reported on again (p. 781) covered the period of three years from April 1959, during which time 634 patients were operated on-507 men and 127 women. Of the 507 male patients no fewer than 132 were rejected from the trial. Of the 375 males accepted approximately equal numbers were allocated to the three operations. Most of those rejected were treated by vagotomy and gastroenterostomy. The surgeons concerned in the trial are to be congratulated in that the operative mortality of this large series of 634 patients was zero.

After a thorough analysis of the follow-up results the authors are unable to make a dogmatic statement about the superiority of any one operation over the others, since the overall clinical results failed to show any statistically significant difference. But there is a bias in favour of vagotomy with antrectomy and of subtotal gastrectomy over vagotomy with gastroenterostomy. The two former operations seem to offer better protection against stomal ulceration and rather better functional results than vagotomy and gastroenterostomy.

These findings must be considered in relation to others. The experience at other centres with regard to operative mortality is not so happy as in the present study. The average mortality in partial gastrectomy is in the region of $2-5 \%$, yet most studies of vagotomy and drainage give a lower mortality in the range of $0.5-1 \%$. Obviously this is an important consideration. Furthermore, the metabolic effects of vagotomy combined with simple drainage are less profound than those following gastrectomy, ${ }^{4}$ and this too must add weight to the arguments for the simpler operation.

Professor Goligher and his colleagues then go on to report at page 787 a more recent study in a series of 175 men with duodenal ulcer treated by total vagotomy and pyloroplasty since January 1963. There were two deaths in the immediate postoperative period due to acute cardiac failure. Two years after operation 158 patients have been interviewed and

\footnotetext{
1 Brit. med. F., 1968, 1, 461.

Cox, A. G., Brit. med. ₹., 1968, 1, 288.

S Goligher, J. C., Pulvertaft, C. N., and Watkinson, G., Brit. med. F., 1964, 1, 455.

- Wastell, C., Postgrad. med. ₹., 1967, 43, 481.
}

examined. Though the follow-up period is comparatively short, there has not been any lower incidence of symptoms of alimentary dysfunction after pyloroplasty than was found in the previous study after vagotomy and gastroenterostomy. Against this is a higher tendency for recurrent ulceration after pyloroplasty than after gastroenterostomy.

These findings, though still somewhat tentative, cast doubt on sweeping statements made by advocates of their own particular favourite procedure in the surgery of duodenal ulceration. Perhaps their greatest importance is in pointing a way to the future. The more carefully designed prospective studies of this type which are carried out the sooner shall we be able to obtain the answers to the many vexing questions which face the surgeon today in his choice of operation for a particular patient suffering from this common affliction.

\section{Controversy in Wilson's Disease}

Wilson's disease has always excited interest and controversy, ${ }^{1}$ and never was this more true than at present, as readers of the New England fournal of Medicine will have realized. The current controversy started after a paper of I. Sternlieb and I. H. Scheinberg, ${ }^{2}$ which described the treatment of symptom-free relatives of patients with the disease with prophylactic penicillamine. Though these relatives had none of the clinical signs of Wilson's disease, they were thought to be homozygous for the abnormal gene because of the finding of a low caeruloplasmin level in the plasma and a high copper concentration in the liver. Of the 34 patients in whom adequate liver-biopsy material was available, five showed no abnormality on light microscopy, eleven had definite cirrhosis, and the remainder showed fatty change with or without portal tract fibrosis. During the period of observation amounting to 142 patient-years for the 42 relatives treated, none has developed signs of the disease. From a retrospective analysis of a group of 121 patients with Wilson's disease the authors estimated that without treatment at least eight of these relatives would have been expected to develop the disorder. Five relatives have now reached or passed the age at which their older siblings became overtly ill with the disease.

The setting up of a properly randomized therapeutic trial would have required withholding treatment from half of these asymptomatic homozygotes. Steinlieb and Scheinberg argued that this was ethically unjustifiable in view of the known beneficial effects of penicillamine therapy in Wilson's disease and the results of their retrospective analysis. Other workers, including J. M. Walshe ${ }^{3}$ and A. J. Levi and his colleagues ${ }^{4}$ in Britain, who have a further 11 asymptomatic relatives on prophylactic penicillamine therapy, would agree with this view. But $\mathrm{H}$. Muench ${ }^{5}$ and some of the statisticians who initially reviewed the paper have their doubts. ${ }^{6}$ Is the statistical evidence sufficiently strong to merit the lifelong commitment of asymptomatic subjects to a drug which produces an

Brit. med. 7., 1967, 4, 435

2 Sternlieb, I., and Scheinberg, I. H., New Engl. f. Med., 1968, 278, 352.

3 Walshe, J. M., New Engl. F. Med., 1968, 278, 795.

'Levi, A. J., Sherlock, S., Scheuer, P. J., and Cumings, J. N., Lancet, $1967,2,575$.

s Muench, H. New Engl. 7. Med., 1968, 278, 796.

6 New Engl. f. Med., 1968, 278, 392

Osborn, S. B., and Walshe, J. M., Clin. Sci., 1964, 27, 319.

* Levi, A. J., and Williams, H. S., Clin. Sci., 1968, 34, 379. 